\title{
Identification of Mycoplasma genitalium from clinical swabs by
}

\section{direct PCR [version 1; peer review: 1 approved, 1 approved}

\section{with reservations]}

\section{Robinson M. Irekwa(D1), Perpetual Ndung'u(iD2, Peter Kipkemboi3, Tonny Teya3, Anne Wanjiru Mwangi ${ }^{3,4}$, Matthew Mutinda ${ }^{3}$, Caroline Njoroge $^{3}$, Joanne Yego ${ }^{3}$, Irumva Vanessa1, Samson Muuo Nzou 3,5}

\begin{abstract}
${ }^{1}$ Department of Molecular Biology and Biotechnology, Pan Africa University Institute of Basic Sciences, Technology and Innovation (PAUSTI-JKUAT), Juja, Kiambu, Kenya

2Department of Parasitology, Jomo Kenyatta University of Agriculture and Technology, Juja, Kiambu, Kenya

${ }^{3}$ Nagasaki University Institute of Tropical Medicine-Kenya Medical Research Institute Project (NUITM-KEMRI-Project), Nairobi, Kenya

${ }^{4}$ Production Department, Kenya Medical Research Institute (KEMRI), Nairobi, Kenya

${ }^{5}$ Institute of Tropical Medicine and Global Health, Nagasaki University, Nagasaki, Japan
\end{abstract}

V1 First published: 26 Nov 2019, 8:1993

https://doi.org/10.12688/f1000research.21218.1

Latest published: 26 Nov 2019, 8:1993

https://doi.org/10.12688/f1000research.21218.1

\begin{abstract}
Mycoplasma genitalium is one of the smallest self-replicating organisms. It is an obligate parasite found in the human genital tract. In men, the bacteria cause both acute and chronic non-gonococcal urethritis (NGU). In women, it has been associated with pelvic inflammatory disease and cervicitis among other related infections. Treatment of $M$. genitalium related infections has been effective using antibiotics such as the macrolides (e.g. azithromycin) and fluoroquinolones. However, there have been recorded cases of resistance to these antibiotics in various parts of the world as a result of a mutation in the 23SrRNA gene, although the antibiotic resistance has not been well established. The aim of this study was to detect $M$. genitalium in 352 swab samples collected from a clinic for sex workers in Nairobi, Kenya. DNA was extracted from the swabs and stored as a crude extract at $-31^{\circ} \mathrm{C}$. The swab lysates were subjected to direct polymerase chain reaction using primers that specifically target the 16S rRNA gene for M. genitalium. A total of 29 samples tested positive for M. genitalium. The data results showed a M. genitalium prevalence of $8.24 \%$ among sex workers in Nairobi, Kenya.
\end{abstract}

\section{Keywords}

Direct PCR, Mycoplasma genitalium

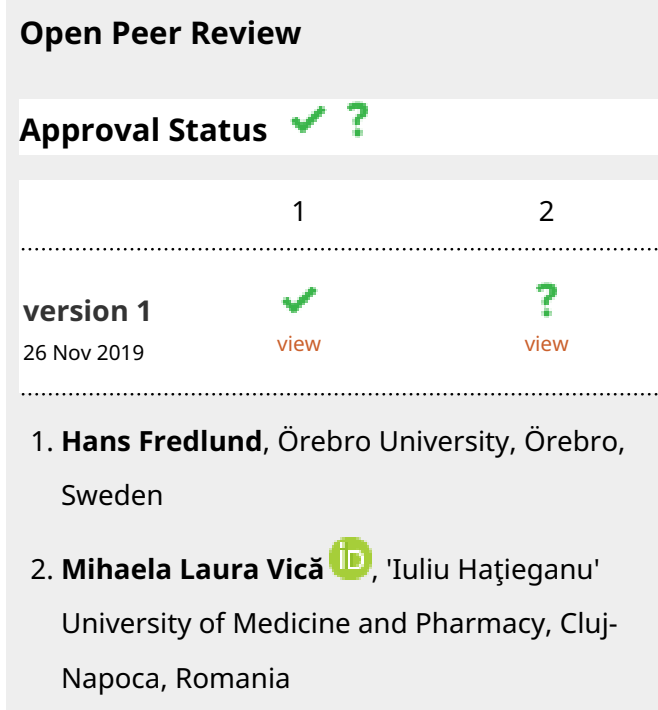

Any reports and responses or comments on the article can be found at the end of the article. 
Corresponding author: Robinson M. Irekwa (robinsonmugo@gmail.com)

Author roles: Irekwa RM: Conceptualization, Methodology; Ndung'u P: Supervision; Kipkemboi P: Methodology; Teya T: Investigation; Wanjiru Mwangi A: Investigation; Mutinda M: Investigation; Njoroge C: Investigation; Yego J: Investigation; Vanessa I: Investigation; Muuo Nzou S: Conceptualization, Supervision

Competing interests: No competing interests were disclosed.

Grant information: This project was funded by the Pan Africa University Institute of Basic Sciences, Technology and Innovation hosted at the Jomo Kenyatta University of Agriculture and Technology (PAUSTI-JKUAT) and Nagasaki University Institute of Tropical MedicineKenya Medical Research Institute project (NUITM-KEMRI).

The funders had no role in study design, data collection and analysis, decision to publish, or preparation of the manuscript.

Copyright: $\odot 2019$ Irekwa RM et al. This is an open access article distributed under the terms of the Creative Commons Attribution License, which permits unrestricted use, distribution, and reproduction in any medium, provided the original work is properly cited.

How to cite this article: Irekwa RM, Ndung'u P, Kipkemboi P et al. Identification of Mycoplasma genitalium from clinical swabs by direct PCR [version 1; peer review: 1 approved, 1 approved with reservations] F1000Research 2019, 8:1993

https://doi.org/10.12688/f1000research.21218.1

First published: 26 Nov 2019, 8:1993 https://doi.org/10.12688/f1000research.21218.1 


\section{Introduction}

Mycoplasma genitalium is an emerging sexually transmitted disease that was first identified and isolated in $1980^{1}$ from men with non-gonococcal urethritis (NGU). Its epidemiology in connection to other STI syndromes been established since nucleic acid amplification assay development in the early $1990 \mathrm{~s}^{2}$. The bacteria have been detected in substantial amounts from men with urethritis and women with cervicitis ${ }^{3}$. $M$. genitalium prevalence in the general population has been studied and found to be ranging between $1-3 \%{ }^{4}$.

M. genitalium is found in roughly $15 \%$ of men with NGU and in $22 \%$ of men with non-chlamydial NGU. However, the associated infections do not have unique clinical symptoms, making it difficult to use clinical signs as a mode of identification ${ }^{5}$. Cervicitis has been described as the female version of male urethritis. M. genitalium is found in $10 \%$ of women with cervicitis $^{6}$. Chlamydial coinfections in women with cervicitis are also common in some settings ${ }^{7}$. M. genitalium is a very fastidious bacterium and culturing of the bacterium is exhaustive and time consuming.

The introduction of polymerase chain reaction (PCR) assays has provided the necessary data for its clinical prevalence ${ }^{8}$. Many assays have been developed for the detection of M. genitalium in human specimens $\mathrm{s}^{8-17}$. Most of these assays are mainly based on the PCR detection technique. Use of these PCR tests have shown that the disease spectrum is similar to those caused by Chlamydia trachomatis and Neisseria gonorrhoeae in both males and females ${ }^{13}$. However, these assays differ in their target DNA sequences, specimen preparation and amplicon detection methods. Many of these detection methods target the 16S rRNA and the $M g P a$ protein genes. Conventional and, more recently, real-time PCR assays have been applied. Most of the detection studies have been conducted in the U.S.A, Europe and Australia, with various strains being discovered. In line with the detection of the bacterial species and its related infections in Africa, more studies need to be conducted on possible strains and their epidemiology. Whether the bacteria have links with other sexually transmitted infections can also be investigated. In this study, it is shown that direct PCR can be applied to the detection of $M$. genitalium from crude DNA extracts. $M$. genitalium prevalence and characteristics among female sex workers have been studied in Kenya and Uganda ${ }^{18-21}$. Its prevalence has also been studied among males who underwent circumcision in order to prevent HIV acquisition in Kisumu, Kenya ${ }^{22}$. However, most of these studies have focused on conventional, real-time PCR or transcription-mediated amplification assays for the detection of $M$. genitalium. This study reports the use of direct PCR for $M$. genitalium detection from crude DNA extracts using specific primers that target the $16 \mathrm{~S}$ rRNA gene.

\section{Methods}

Ethical statement

This study was approved by the Jomo Kenyatta University of Agriculture and Technology Institutional Ethics Review Committee (JKUAT-IERC): reference number JKU/2/4/896B. The swab samples were collected with written informed consent for the performance of further analysis.

\section{Source of samples}

The samples used in this study were collected as part of the sex workers outreach program (SWOP) central business district clinic in Nairobi, Kenya. As part of this program, patients who showed STI symptoms and consented to the study were sampled by taking vaginal swabs. The specimens were then put into sterile containers and transported to the Pan Africa Hub Laboratory (NUITM-KEMRI) within an hour and stored at $-80^{\circ} \mathrm{C}$. Anonymized samples were retrieved for use in this study.

\section{Sample preparation}

The 352 swab lysates were prepared using the MightyPrep reagent for DNA (TAKARA BIO INC, Kusatsu, Shiga Prefecture, Japan; Cat No: 9182) using the manufacturer's protocol with a slight modification. Swabs were cut and put into $1.5 \mathrm{ml}$ Eppendorf tubes. A total of $200 \mathrm{uL}$ of the MightyPrep reagent was added to the tubes and later centrifuged at $15 \mathrm{krpm}$ for one minute. The tubes were then transferred to a heated block at $95^{\circ} \mathrm{C}$ with shaking at $800 \mathrm{rpm}$ for 15 minutes. Later, the tubes were cooled down by lowering the heat block temperature to $25^{\circ} \mathrm{C}$, followed by hard vortexing of each tube for one minute and, finally, centrifugation at $15 \mathrm{krpm}$ for two minutes before storage at $-31^{\circ} \mathrm{C}$.

\section{Direct PCR}

The master mix was prepared using the manufacturer's protocol with slight modifications (Hotstar Taq ${ }^{\circledR}$ Master Mix Kit 2.5

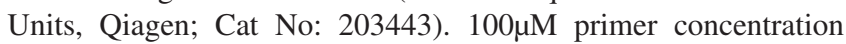
was achieved by adding $303 \mu \mathrm{l}$ and $353 \mu \mathrm{l}$ of Tris EDTA (Nippon Gene Company Ltd, Japan, Cat No: 314-90021; 10mM Tris-HCl [pH 8.0], 1mM EDTA [pH 8.0]) to the forward and reverse primers (Table 1; Sigma-Aldrich, Darmstadt, Germany), respectively. The primers (Table 1) targeted the 16S rRNA gene $^{23}$ giving 433bp amplicon size fragments. Master mix components were: RNase- free water $(1 \mathrm{x}=7.84 \mu \mathrm{l})$; primer $\operatorname{mix}(1 \mathrm{x}=0.08 \mu \mathrm{l}, 0.2 \mu \mathrm{M}$ of each primer $)$; and HotStar $\mathrm{Taq}^{\circledR}$ master mix $(2 \mathrm{x})$, comprised of 2.5 units HotStarTaq DNA polymerase $(1 \mathrm{x}=10 \mu \mathrm{l}), 1 \mathrm{x}$ PCR buffer $(1 \mathrm{x}$, contains $1.5 \mathrm{mM}$ $\left.\mathrm{MgCl}_{2}\right)$ and $200 \mu \mathrm{M}$ of each dNTP.

After vortexing the master mix for five seconds, $18 \mu \mathrm{l}$ was aliquoted to each of the labeled 96 PCR tubes. $2 \mu \mathrm{l}$ of the swab lysates was added to each tube to make a final reaction

Table 1. Primer sequences.

Forward primer

Reverse primer

MG16-45F (TACATGCAAGTCGATCGGAAGTAGC) MG16-447R (AAACTCCAGCCATTGCCTGCTAG-3') 
volume of $20 \mu \mathrm{l}$ and the tubes were finger tapped for five seconds to mix the contents. A positive control (M. genitalium positive sample) and negative control (PCR water) were used. The PCR tubes were placed in the SimpliAmp ${ }^{\mathrm{TM}}$ Thermal Cycler (Applied Biosystems) and run under the following reaction conditions.

An initial antibody inactivation step was carried at $95^{\circ} \mathrm{C}$ for 15 minutes, followed by 35 cycles of: denaturation at $94^{\circ} \mathrm{C}$ for 60 seconds, annealing at $67^{\circ} \mathrm{C}$ for 60 seconds and extension at $72^{\circ} \mathrm{C}$ for 60 seconds. A final extension step was carried out at $72^{\circ} \mathrm{C}$ for 10 minutes, followed by the final hold at $4^{\circ} \mathrm{C}$ for $\infty$.

\section{Agarose gel electrophoresis}

The PCR products were subjected to gel electrophoresis using $2.5 \%$ agarose gel SeaKem ${ }^{\circledR}$ GTG $^{\circledR}$ agarose (Lonza, Rockland, ME, USA; Cat No: 50074) at $100 \mathrm{~V}$ for 45 minutes. 6x loading dye (Nippon Gene; Cat No: 314-90261) was diluted with sample to make $1 \mathrm{x}$ and loaded onto the gel. The 100bp GelPilot $^{\circledR}$ Ladder marker (Qiagen; Cat No: 239035) was used. The gels were stained with $2 \mathrm{x}$ GelRed ${ }^{\mathrm{TM}}$ Nucleic Acid Gel Stain (Biotium; Cat No: 41003) for one hour on a shaker. The image was viewed using the UltraSlim UV Transilluminator (Maestrogen).

\section{Amplification of the PCR products}

The PCR products were subjected to another PCR. Master mix components were as described above. $18 \mu \mathrm{l}$ was aliquoted into the PCR tubes. $1 \mu \mathrm{l}$ of the sample products was added to the tubes to make a $19 \mu \mathrm{l}$ final volume. The PCR tubes were placed in the SimpliAmp ${ }^{\mathrm{TM}}$ Thermal Cycler (Applied Biosystems) and run under the following reaction conditions.

An initial antibody inactivation step was carried out at $95^{\circ} \mathrm{C}$ for 15 minutes, followed by 30 cycles of: denaturation at $94^{\circ} \mathrm{C}$ for 60 seconds, annealing at $69^{\circ} \mathrm{C}$ for 60 seconds and extension at $72^{\circ} \mathrm{C}$ for 60 seconds. A final extension step was carried out at $72^{\circ} \mathrm{C}$ for 10 minutes, followed by the final hold at $4^{\circ} \mathrm{C}$ for $\infty$.

The products were run on a $2.0 \%$ agarose gel at $100 \mathrm{~V}$ for 40 minutes. A 3000bp ladder (Solis BioDyne, Tartu, Estonia) was used. The gels were stained using 2x GelRed for one hour and viewed under an UltraSlim UV Transilluminator.

\section{Results}

A total of 352 lysates were analyzed in this study. The results show evidence for the presence of $M$. genitalium from swabs taken from the female sex workers who were sampled. 352 lysates were prepared using the MightyPrep reagent.

\section{M. genitalium detection}

M. genitalium was detected among the 352 swab lysates. Examples of $M$. genitalium detection are shown in Figure 3 to Figure 4. Figure 1 shows clear bands at positions 1, 2, 9, 10 and 17 on a 26-well agarose gel. The same kind of bands can be seen in Figure 2 at positions 9, 10, 11 and 18. The positive and negative controls are at positions 24 and 25 , respectively, on each gel. A 600bp ladder was used at positions 1 and 26 to track the $M$. genitalium amplicon sizes of interest.

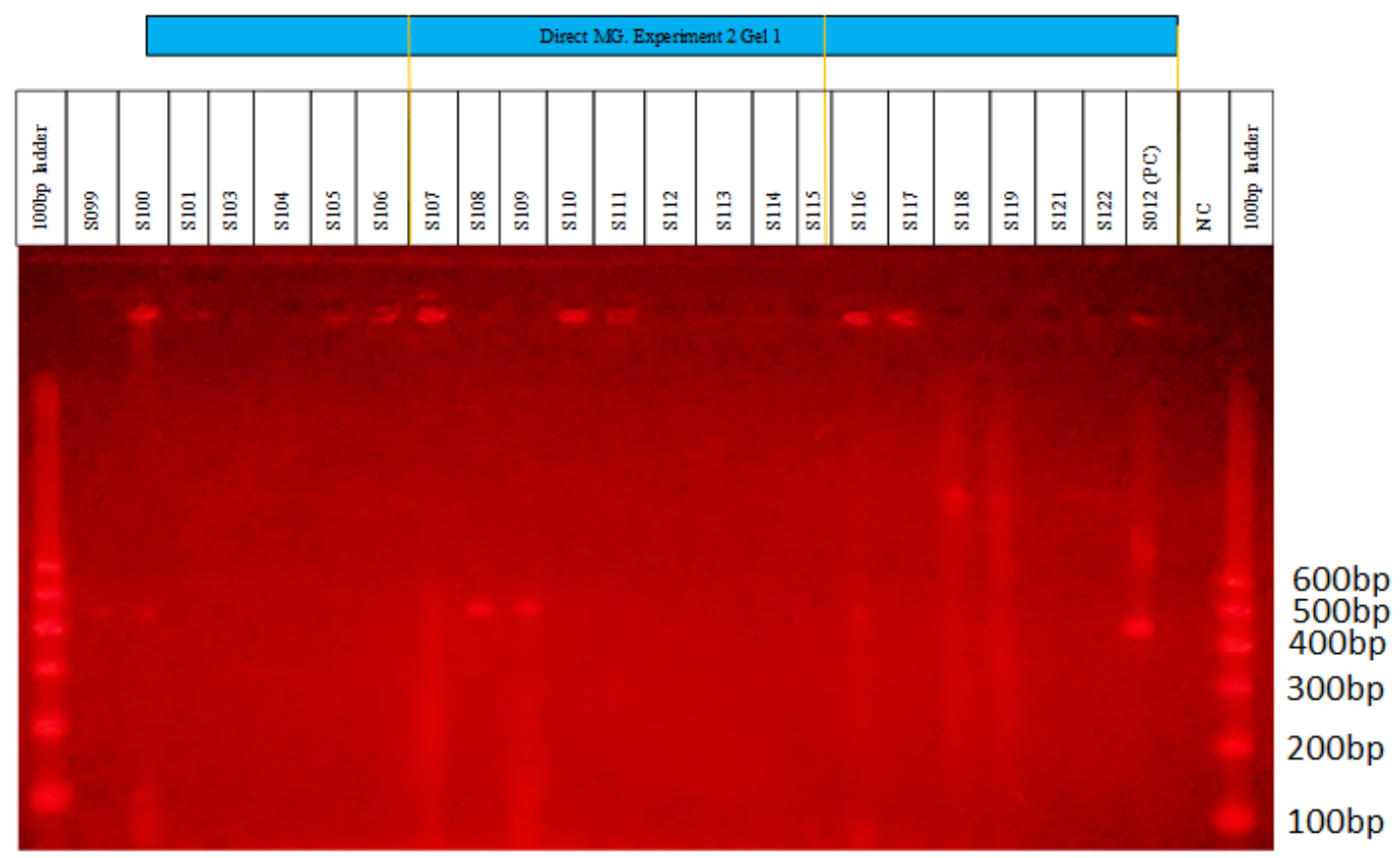

Figure 1. First representative gel for Mycoplasma genitalium detection using direct PCR. Ultraviolet camera gel image showing 22 samples run on a 26-well gel. The ladder is at positions 1 and 26 (Gel Pilot $\left.{ }^{\circledR}\right)$. Clear Mycoplasma genitalium positive bands can be seen at positions 1, 2, 9, 10 and 17 (Sexually transmitted infection lysates S099, S100, S108, S109 and S116, respectively). The positive control (PC) and negative control (NC) are at positions 24 and 25, respectively. 


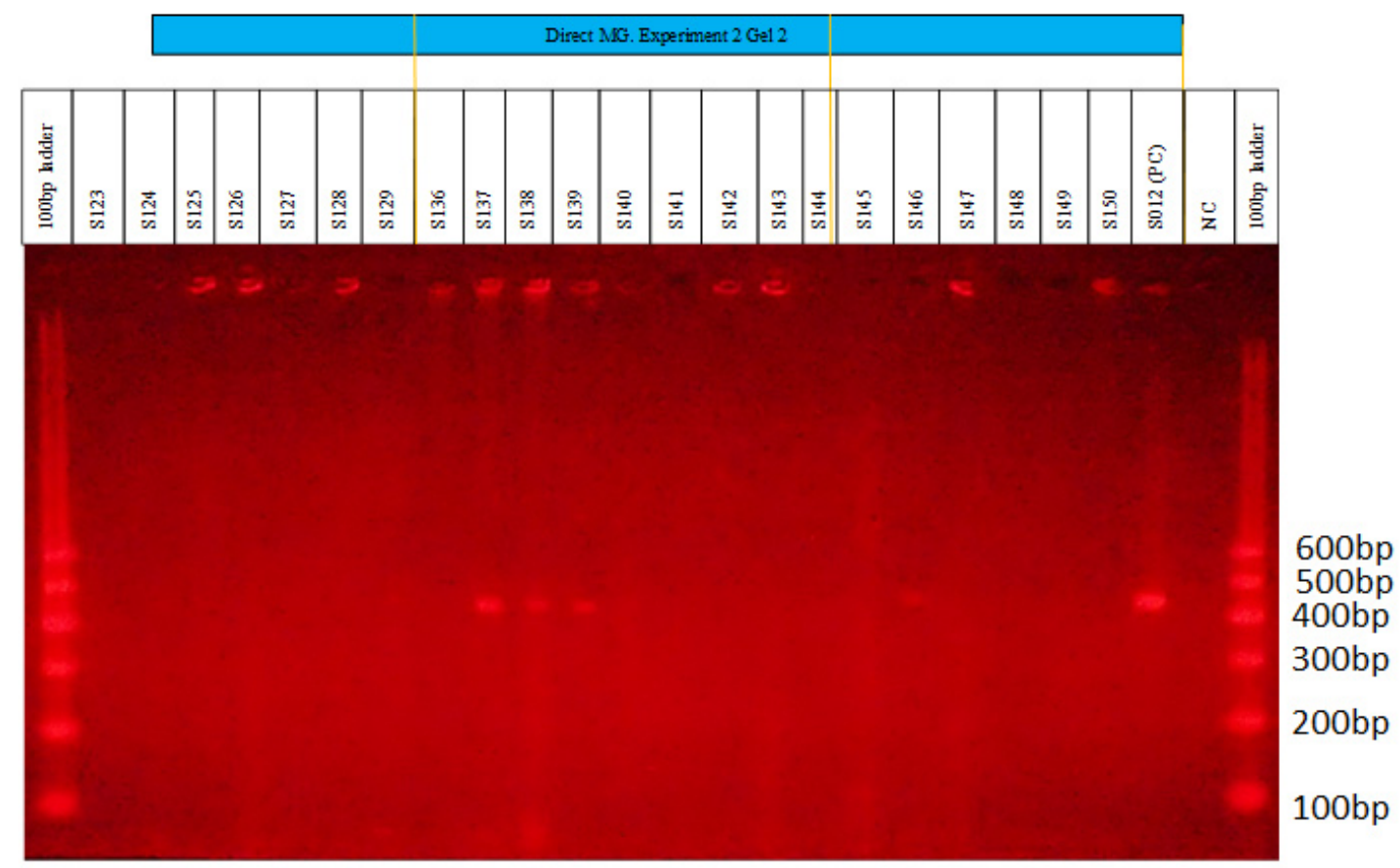

Figure 2. Second representative gel for the detection of Mycoplasma genitalium using direct PCR. UV camera gel image showing the 22 samples run on a 26-well gel. The first and last wells represent the ladder (GelPilot ${ }^{\circledR}$ ). Clear Mycoplasma genitalium positive bands can be seen at positions 9, 10, 11 and 18 (Iysates S137, S138, S139 and S146, respectively). The positive control (PC) is shown at position 24 and the negative control (NC) at position 25.

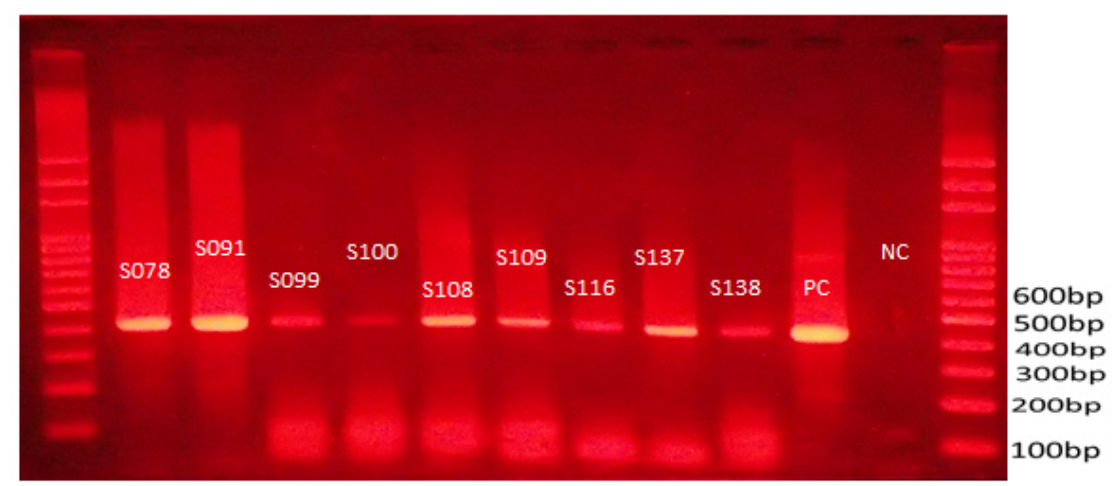

Figure 3. First representative gel showing the amplification of the PCR products. The selected PCR products were amplified: the above image shows the first nine PCR products run on a gel after the amplification was conducted. The ladder (Solis BioDyne) is at the first and last lanes. The positive control (PC) is at lane 11, while the negative control (NC) is at lane 12.

The PCR products were subjected to another amplification reaction. After the reaction, the products were run on a 13-well agarose gel. A 3000bp ladder was loaded on positions 1 and 13 , with the positive and negative controls at positions 11 and 12, respectively, as can be seen in Figure 3 and Figure 4. Out of the 352 swab lysates used, 29 tested positive for M. genitalium.

\section{M. genitalium prevalence}

M. genitalium prevalence among the cohort of female sex workers was found to be at $8.24 \%$ (29/352), showing one out of eight patients had $M$. genitalium related infections.

\section{Discussion}

Recently, DNA amplification protocols using PCR have been employed in the detection of $M$. genitalium. To investigate the presence of $M$. genitalium from the clinical swab samples collected from a clinic for sex workers in Nairobi, Kenya, a direct PCR technique was used for the detection of $M$. genitalium. This technique involves the use of target-specific primers to select the DNA of interest from a crude extract. The study detected $M$. genitalium using primers that bind to the 16SrRNA gene from the crude DNA extract. Jensen and his colleagues ${ }^{23}$ developed a wide range of primers 


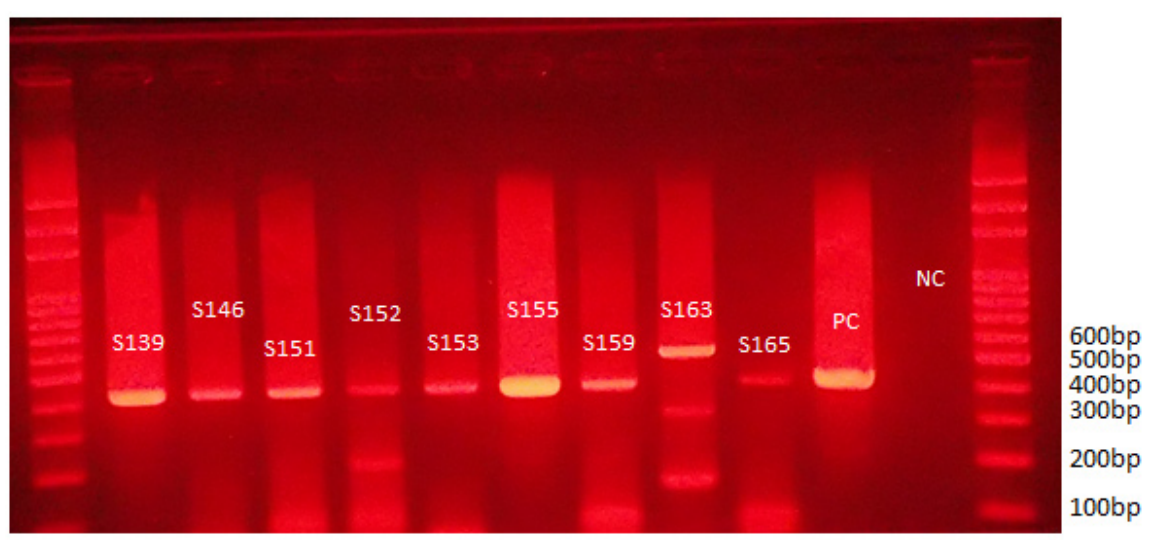

Figure 4. Second representative gel showing the amplification of the PCR products. This gel shows PCR products of the samples that were selected for amplification. The first and last lane contain the ladder marker (Solis BioDyne), the PCR products run from lanes 2 to 10 and the positive control (PC) is at position 11, while the negative control (NC) is at position 12.

that target the $16 \mathrm{~S}$ rRNA gene, producing different amplicon sizes. A novel PCR was used ${ }^{24}$ to detect $M$. genitalium using oligonucleotide primers that corresponded to sequences along its $16 \mathrm{~S}$ rRNA gene.

The study was able to detect $29 \mathrm{M}$. genitalium positive samples out of the 352 lysates. However, the challenge experienced with this method was non-specific amplification, realized from the multiple fragments produced. A possible solution to this is in the use of more precise target-specific primers to prevent the amplification of genes with closely related sequences. Application of this method can be a remedy to the constant loss of DNA due to long extraction processes, at the same time maintaining its quality for further downstream analysis.

M. genitalium prevalence was shown to be at $8.24 \%$. This shows that one out of every eight patients sampled was positive for $M$. genitalium related infections. Balkus and colleagues in 2018 were able to detect M. genitalium from 25 out of $221(11.3 \%)$ women from Kenya and the US ${ }^{25}$. Prevalence rates of $12.9 \%^{18}$ and $16 \%{ }^{19}$ have also been reported among sex workers in Nairobi, Kenya. The prevalence obtained in this study therefore does not show any significant drop in M. genitalium infections. Despite better and improved access to healthcare, $M$. genitalium infections seem to continue to be a burden. Possible reasons might be due to having multiple sex partners ${ }^{26}$ or antibiotic resistance to drugs of choice such as macrolides and fluoroquinolones ${ }^{27,28}$

Overall, the prevalence results suggest that more measures need to be taken to control M. genitalium infections. Awareness campaigns need to be carried out to sensitize people on preventive measures rather than taking potential risks that may lead to exposure to the infection. Studies need to be done to investigate $M$. genitalium drug resistance. This will be helpful in informing policy and practice. As a result, screening can be done in patients to check for resistance before prescribing medication.

\section{Data availability}

Underlying data

Figshare: Detection of Mycoplasma genitalium using Direct PCR. https://doi.org/10.6084/m9.figshare.10282691.v129.

This project contains the following underlying data:

- Direct PCR 1.docx - Direct PCR 4.docx (lists of the samples tested for Mycoplasma genitalium in four sets of 88 samples)

- Exp 1 Gel 1.JPG - Exp 4 Gel 4.JPG (gel electrophoresis of PCR products; 100bp GelPilot ${ }^{\circledR}$ Ladder marker [Qiagen] at positions 1 and 26, samples from positions 2 to 23 , positive control at position 24 and negative control at position 25)

- Amplification Gel 1.JPG - Amplification Gel 3.JPG (gel electrophoresis of the amplified products; 100bp ladder [Solis BioDyne] at positions 1 and 13, samples from positions 2 to 10 , positive control at position 11 and negative control at position 12)

- Amplification Gel 4.JPG (gel electrophoresis of the amplified products; 100bp ladder [Solis BioDyne] at positions 1 and 13 , samples from positions 2 to 7 , positions 8,11 and 12 contain no samples [blanks], positive control at position 9 and negative control at position 10).

Data are available under the terms of the Creative Commons Zero "No rights reserved" data waiver (CC0 1.0 Public domain dedication).

\section{Acknowledgements}

The authors would like to thank the Nagasaki University Institute of Tropical Medicine in collaboration with the Kenya Medical Research Institute (NUITM-KEMRI), The Pan Africa University Institute of Science Technology and Innovation hosted at the Jomo Kenyatta University of Agriculture and Technology, Kenya (PAUSTI-JKUAT) for the research conceptualization and support. 
1. Huengsberg M: Sexually Transmitted Diseases. 3rd ed. Ed King K Holmes, P Frederick Sparling, Per-Anders Mardh, Stanley M Lemon, Walter E Stamm, Peter Piot, Judith N Wasserheit. \$170.50. New York: McGraw Hill, 1999. Sex Transm Infect. 2000; 76(6): 498 Publisher Full Text

2. Tully JG, Cole RM, Taylor-Robinson D, et al:: A Newly Discovered Mycoplasma In The Human Urogenital Tract. Lancet. 1981; 1(8233): 1288-91. PubMed Abstract | Publisher Full Text

3. Taylor-Robinson D, Jensen JS: Mycoplasma genitalium: from Chrysalis to Multicolored Butterfly. Clin Microbiol Rev. 2011; 24(3): 498-514. PubMed Abstract | Publisher Full Text | Free Full Text

4. Andersen B, Sokolowski I, Ostergaard L, et al:: Mycoplasma genitalium: prevalence and behavioural risk factors in the general population. Sex Transm Infect. 2007; 83(3): 237-41.

PubMed Abstract | Publisher Full Text | Free Full Text

5. Wetmore CM, Manhart LE, Lowens MS, et al: Ureaplasma urealyticum Is Associated With Nongonococcal Urethritis Among Men With Fewer Lifetime Sexual Partners: A Case-Control Study. J Infect Dis. 2011; 204(8): 1274-82. PubMed Abstract | Publisher Full Text | Free Full Text

6. Brunham RC, Paavonen J, Stevens CE, et al: Mucopurulent cervicitis--the ignored counterpart in women of urethritis in men. N Engl J Med. 1984; 311(1): 1-6. PubMed Abstract | Publisher Full Text

7. Gaydos C, Maldeis NE, Hardick A, et al.: Mycoplasma genitalium as a Contributor to the Multiple Etiologies of Cervicitis in Women Attending Sexually Transmitted Disease Clinics. Sex Transm Dis. 2009; 36(10): 598-606. PubMed Abstract | Publisher Full Text | Free Full Text

8. Palmer HM, Gilroy CB, Furr PM, et al:: Development and evaluation of the polymerase chain reaction to detect Mycoplasma genitalium. FEMS Microbiol Lett. 1991; 61(2-3): 199-203. PubMed Abstract | Publisher Full Text

9. Wroblewski JK, Manhart LE, Dickey KA, et al:: Comparison of transcriptionmediated amplification and PCR assay results for various genital specimen types for detection of Mycoplasma genitalium. J Clin Microbiol. 2006; 44(9): 3306-12.

PubMed Abstract | Publisher Full Text | Free Full Text

10. Björnelius E, Lidbrink P, Jensen JS: Mycoplasma genitalium in non-gonococcal urethritis--a study in Swedish male STD patients. Int J STD AIDS. 2000; 11(5): 292-6.

PubMed Abstract | Publisher Full Text

11. Deguchi T, Gilroy CB, Taylor-Robinson D: Comparison of two PCR-based assays for detecting Mycoplasma genitalium in clinical specimens. Eur J Clin Microbiol Infect Dis. 1995; 14(7): 629-31.

PubMed Abstract | Publisher Full Text

12. Dutro SM, Hebb JK, Garin CA, et al:: Development and performance of a microwell-plate-based polymerase chain reaction assay for Mycoplasma genitalium. Sex Transm Dis. 2003; 30(10): 756-63.

PubMed Abstract | Publisher Full Text

13. Jensen JS: Mycoplasma genitalium: the aetiological agent of urethritis and other sexually transmitted diseases. J Eur Acad Dermatol Venereol. 2004; 18(1): $1-11$.

PubMed Abstract | Publisher Full Text

14. Jensen JS, Uldum SA, Søndergård-Andersen J, et al.: Polymerase chain reaction for detection of Mycoplasma genitalium in clinical samples. $J$ Clin Microbiol. 1991; 29(1): 46-50.

PubMed Abstract | Free Full Text

15. Jurstrand M, Jensen JS, Fredlund H, et al.: Detection of Mycoplasma genitalium in urogenital specimens by real-time PCR and by conventional PCR assay. $J$ Med Microbiol. 2005; 54(Pt 1): 23-9.

PubMed Abstract | Publisher Full Text

16. Yoshida T, Deguchi T, Ito M, et al:: Quantitative detection of Mycoplasma genitalium from first-pass urine of men with urethritis and asymptomatic men by real-time PCR. J Clin Microbiol. 2002; 40(4): 1451-5. PubMed Abstract | Publisher Full Text | Free Full Text

17. Yoshida T, Maeda S, Deguchi T, et al:: Rapid Detection of Mycoplasma genitalium, Mycoplasma hominis, Ureaplasma parvum, and Ureaplasma urealyticum Organisms in Genitourinary Samples by PCR-Microtiter Plate Hybridization Assay. J Clin Microbiol. 2003; 41(5): 1850-5.

PubMed Abstract | Publisher Full Text | Free Full Text

18. Gomih-Alakija A, Ting J, Mugo N, et al.: Clinical characteristics associated with Mycoplasma genitalium among female sex workers in Nairobi, Kenya. J Clin Microbiol. 2014; 52(10): 3660-6.

PubMed Abstract | Publisher Full Text | Free Full Text

19. Cohen CR, Nosek M, Meier A, et al:: Mycoplasma genitalium infection and persistence in a cohort of female sex workers in Nairobi, Kenya. Sex Transm Dis. 2007; 34(5): 274-9. PubMed Abstract

20. Vandepitte J, Muller E, Bukenya J, et al: Prevalence and correlates of Mycoplasma genitalium infection among female sex workers in Kampala, Uganda. J Infect Dis. 2011; 205(2): 289-96. PubMed Abstract | Publisher Full Text

21. Vandepitte J, Weiss HA, Kyakuwa N, et al.: Natural history of Mycoplasma genitalium Infection in a Cohort of Female Sex Workers in Kampala, Uganda. genitalium Infection in a Cohort of Sex Transm Dis. 2013; 40(5): 422-7.
PubMed Abstract | Publisher Full Text | Free Full Text

22. Mehta SD, Gaydos C, Maclean I, et al: The effect of medical male circumcision on urogenital mycoplasma genitalium among men in kisumu, kenya. Sex Trans Dis. 2012; 39(4): 276-80.

PubMed Abstract | Publisher Full Text | Free Full Text

23. Jensen JS, Borre MB, Dohn B: Detection of Mycoplasma genitalium by PCR Amplification of the 16S rRNA Gene. J Clin Microbiol. 2003; 41(1): 261-6. PubMed Abstract | Publisher Full Text | Free Full Text

24. Eastick K, Leeming JP, Caul EO, et al.: A novel polymerase chain reaction assay to detect Mycoplasma genitalium. Mol Pathol. 2003; 56(1): 25-8. PubMed Abstract | Publisher Full Text | Free Full Text

25. Balkus JE, Manhart LE, Jensen JS, et al:: Mycoplasma genitalium Infection in Kenyan and US Women. Sex Transm Dis. 2018; 45(8): 514-21. PubMed Abstract | Publisher Full Text | Free Full Text

26. Pepin J, Labbé AC, Khonde N, et al.: Mycoplasma genitalium: an organism commonly associated with cervicitis among West African sex workers. Sex Transm Infect. 2005; 81(1): 67-72. PubMed Abstract | Publisher Full Text | Free Full Text

27. Anderson T, Coughlan E, Werno A: Mycoplasma genitalium Macrolide and Fluoroquinolone Resistance Detection and Clinical Implications in a Selected Cohort in New Zealand. J Clin Microbiol. 2017; 55(11): 3242-3248. PubMed Abstract | Publisher Full Text | Free Full Text

28. Tagg K, Jeoffreys $\mathrm{N}$, Couldwell DL, et al:: Fluoroquinolone and macrolide resistance-associated mutations in Mycoplasma genitalium. J Clin Microbiol. 2013; 51(7): 2245-2249. PubMed Abstract | Publisher Full Text | Free Full Text

29. Irekwa R, Nzou SM: Detection of Mycoplasma genitalium using Direct PCR. figshare. Dataset. 2019. http://www.doi.org/10.6084/m9.figshare.10282691.v1 


\section{Open Peer Review}

\section{Current Peer Review Status:}

\section{Version 1}

Reviewer Report 14 July 2020

https://doi.org/10.5256/f1000research.23360.r66861

(C) 2020 Vică M. This is an open access peer review report distributed under the terms of the Creative Commons Attribution License, which permits unrestricted use, distribution, and reproduction in any medium, provided the original work is properly cited.

\section{Mihaela Laura Vică}

Department of Cell and Molecular Biology, 'Iuliu Haţieganu' University of Medicine and Pharmacy, Cluj-Napoca, Romania

This paper presents a laboratory method used for detection of Mycoplasma genitalium in swab samples collected from sex workers. The authors provide descriptions of the method used and the results obtained. I consider that, in order to be indexed, the paper needs some revisions and explanations.

\section{Abstract}

The paragraph on treatment and antibiotic resistance is not necessary because they are not the subject of this article.

\section{Introduction}

The phrase "Most of the detection studies have been conducted in the U.S.A, Europe and Australia, with various strains being discovered" requires citations from literature to exemplify what is stated. The phrase "In this study, it is shown that direct PCR can be applied to the detection of $M$. genitalium from crude DNA extracts." should not be placed in this section. It must be moved to the Discussions section.

\section{Methods}

In Sample preparation and Direct PCR sections, the authors declare that they used the manufacturer's protocol "with slight modifications". What are these changes and for what purpose were they made?

A positive control (M. genitalium positive sample) was used. Where does it come from? Why two PCR amplifications were made? The authors should explain why they have amplified PCR products.

\section{Results}

I think two Figures are enough: a representative gel for direct PCR and a representative gel for the 
amplification of the PCR products.

There are mistakes in the legends of the Figures regarding the positive positions: e.g. in Figure 1 "The ladder is at positions 1 and 26" and "Clear Mycoplasma genitalium positive bands can be seen at positions 1, 2, 9, 10 and 17".

How do you explain that in Figure 4 the band corresponding to sample S163 is at a different level than the others?

\section{Discussion}

There is too little discussion about the technique used.

Is the work clearly and accurately presented and does it cite the current literature? Partly

Is the study design appropriate and is the work technically sound? Partly

Are sufficient details of methods and analysis provided to allow replication by others? Yes

If applicable, is the statistical analysis and its interpretation appropriate?

\section{Not applicable}

Are all the source data underlying the results available to ensure full reproducibility? Yes

Are the conclusions drawn adequately supported by the results?

Partly

Competing Interests: No competing interests were disclosed.

Reviewer Expertise: molecular biology, microbiology

I confirm that I have read this submission and believe that I have an appropriate level of expertise to confirm that it is of an acceptable scientific standard, however I have significant reservations, as outlined above.

Author Response 12 Oct 2021

Robinson Irekwa, Pan Africa University Institute of Basic Sciences, Technology and Innovation (PAUSTI-JKUAT), Juja, Kiambu, Kenya

Thank you for the comments given, will work on the sections. Truly appreciate

Competing Interests: No competing interests were disclosed 


\section{https://doi.org/10.5256/f1000research.23360.r59417}

(C) 2020 Fredlund $\mathbf{H}$. This is an open access peer review report distributed under the terms of the Creative Commons Attribution License, which permits unrestricted use, distribution, and reproduction in any medium, provided the original work is properly cited.

\section{Hans Fredlund}

World Health Organization Collaborating Centre for Gonorrhoea and Other Sexually Transmitted Infections (STIs), National Reference Laboratory for STIs, Department of Laboratory Medicine, Faculty of Medicine and Health, Örebro University, Örebro, Sweden

A commecial PCR method to detect M.genitalium was used in this study and a prevalence of $8 \%$ was found in female sex workers in Nairobi, Kenya. The manuscript is well written. It is of interest to perform such studies in many countries and cities globally to follow and understand the epidemiology of this STI. Of that reason the study can be accepted for indexing as it is. What is not studied is the antibiotic sensitivity of M.genitalium. In coming studies this has to be performed.

Is the work clearly and accurately presented and does it cite the current literature? Yes

Is the study design appropriate and is the work technically sound? Yes

Are sufficient details of methods and analysis provided to allow replication by others? Yes

If applicable, is the statistical analysis and its interpretation appropriate? Not applicable

Are all the source data underlying the results available to ensure full reproducibility? Yes

Are the conclusions drawn adequately supported by the results? Yes

Competing Interests: No competing interests were disclosed.

Reviewer Expertise: Infectious diseases and microbiology, epidemiology especially in the area of Neisseria sp and STI.

I confirm that I have read this submission and believe that I have an appropriate level of expertise to confirm that it is of an acceptable scientific standard.

Author Response 12 Oct 2021

Robinson Irekwa, Pan Africa University Institute of Basic Sciences, Technology and 
Innovation (PAUSTI-JKUAT), Juja, Kiambu, Kenya

Thank you Dr. Huns Fredlund.

Competing Interests: No competing interests were disclosed.

The benefits of publishing with F1000Research:

- Your article is published within days, with no editorial bias

- You can publish traditional articles, null/negative results, case reports, data notes and more

- The peer review process is transparent and collaborative

- Your article is indexed in PubMed after passing peer review

- Dedicated customer support at every stage

For pre-submission enquiries, contact research@f1000.com 